\title{
Cardiorenal Syndrome in Hypertensive Rats: Microalbuminuria, Inflammation and Ventricular Hypertrophy
}

\author{
M. MOUBARAK ${ }^{1}$, H. JABBOUR ${ }^{2}$, V. SMAYRA ${ }^{2}$, E. CHOUERY ${ }^{3}$, Y. SALIBA ${ }^{1}$, \\ V. JEBARA ${ }^{4}$, N. FARÈS ${ }^{1}$
}

${ }^{1}$ Laboratoire de Physiologie et Physiopathologie, Faculté de Médecine, Université Saint Joseph, Beyrouth, Liban, ${ }^{2}$ Faculté de Médecine, Université Saint Joseph, Beyrouth, Liban, ${ }^{3}$ Unité de Génétique Médicale, Faculté de Médecine, Université Saint Joseph, Beyrouth, Liban, ${ }^{4}$ Laboratoire de Recherche en Sciences Chirurgicales, Faculté de Médecine, Université Saint Joseph, Beyrouth, Liban

Received January 4, 2011

Accepted September 1, 2011

On-line December 20, 2011

\section{Summary}

The aim of our study was to evaluate a possible association between microalbuminuria (MA), several low-grade inflammation factors and left ventricular hypertrophy (LVH) by using a pharmacological approach. This may provide new insights into the pathophysiologic mechanisms of the cardiorenal syndrome (CRS) linking early renal impairment with elevated cardiovascular risk. Two kidney-one clip (2K-1C) renovascular hypertension was induced in 24 male Wistar rats (220-250 g). After the development of hypertension, rats were divided into four groups: $2 \mathrm{~K}-1 \mathrm{C}$ (untreated), calcium channel blocker (amlodipine-treated), angiotensin receptor blocker (losartan-treated) and peripheral vasodilator (hydralazine-treated), which were treated for 10 weeks. Rats in the $2 \mathrm{~K}-1 \mathrm{C}$ group had all developed hypertension, a significant increase in plasma levels of tumor necrosis factor alpha (TNF-a), interleukin 6 (IL-6), brain natriuretic peptide (BNP) and C-reactive protein (CRP). Moreover MA and creatininaemia underwent a significant increase. Under treatment decreases were observed in systolic blood pressure (SBP), TNF-a, CRP, IL-6, BNP concentrations and creatininaemia. These results were related to the absence of MA which was significantly associated with reductions in cardiac mass and hypertrophy markers (BNP and $\beta-M H C$ gene expression) as well as renal interstitial inflammation. In conclusion, our results suggest that the reduction of MA is correlated with the decrease of the inflammatory components and seems to play an important role in protecting against cardiac hypertrophy and renal injury.

\section{Key words}

Microalbuminuria • Inflammation • Left ventricular hypertrophy

\section{Corresponding author}

N. Farès, Laboratoire de Physiologie et Physiopathologie, Faculté de Médecine, Université Saint Joseph, rue de Damas, B.P. 115076, Riad el Solh, Beyrouth 1107 2180, Liban. Fax: + 9611421 023. E-mail: nassim.fares@usj.edu.lb

\section{Introduction}

The interdependent relationship between cardiac and renal function is known as the cardiorenal syndrome (CRS), where the dysfunction of one leads to the alteration of the second (Heywood 2004). Microalbuminuria (MA) and low-grade inflammation seem to be important key risk factors contributing to the development of left ventricular hypertrophy (LVH) and renal function loss within the CRS. LVH is a target organ damage, a common manifestation of hypertension, and an independent predictor of adverse cardiovascular outcome (Vakili et al. 2001).

The involvement of low-grade inflammation in the development and pathophysiology of hypertension has been already highlighted (Bautista et al. 2005). C-reactive protein (CRP) level, an important serum marker of inflammation, has emerged as one of the most powerful independent predictors of risk for cardiovascular disease (CVD) in the adult population 
(Blake and Ridker 2003, Kaptoge et al. 2010). Also, its levels are generally elevated in patients with hypertension and in general populations, and high CRP may even precede and predict the development of arterial hypertension (Pedrinelli et al. 2004, Sesso et al. 2003, Yuyun et al. 2004). Other inflammatory components such as tumor necrosis factor $\alpha(\mathrm{TNF}-\alpha)$, interleukin $1 \beta$ and 6 (IL-1 $\beta$ and IL-6) may also have important implications in CVD (Navarro-Gonzalez et al. 2008, Peeters et al. 2001, Tzoulaki et al. 2005).

MA, a marker of systemic inflammation and early kidney damage, has also been shown to predict CVD in patients with diabetes, hypertension as well as in seemingly healthy individuals (Arnlov et al. 2005, De Zeeuw et al. 2006, Parving et al. 2006). Moreover, increased urinary albumin excretion (UAE) is associated with heart failure onset in various community populations (Bahrami et al. 2008, Carr et al. 2005, Ingelsson et al. 2007, Kistorp et al. 2005, Okin et al. 2008).

Epidemiological studies have shown that CRP is associated with MA in diabetic, non-diabetic (Festa et al. 2000, Marcovecchio et al. 2008) and hypertensive persons (Assadi 2008, Salles et al. 2007, Stuveling et al. 2004, Tsioufis et al. 2006). The association between MA and the cardiovascular risk also suggests that the link between MA and elevated blood pressure may be mediated by inflammation (Wang et al. 2005). Therefore, one would expect MA to be not only a predictor of cardiovascular risk but also a target for treatment (Ibsen et al. 2005). Treatment with renin-angiotensin aldosterone system (RAAS) inhibitors has a well-known anti-proteinuric effect besides lowering blood pressure (Mancia et al. 2007).

Although some studies have shown an association between MA, inflammation and $\mathrm{LVH}$, the link between several inflammatory components altogether with MA and LVH, as well as their behavior and effect on cardiac and renal functions following MA-lowering therapy in hypertension, remain vague. We previously found a correlation between the development of MA and brain natriuretic peptide (BNP), a marker of LVH, within the CRS (Saliba et al. 2010). We ought to study on the same two kidney-one clip (2K-1C) rat model, the link between MA, LVH, renal function and different inflammatory constituents by a pharmacological approach using losartan, an angiotensin receptor blocker (ARB), and other blood pressure-lowering drugs with less antialbuminuric effects: amlodipine, a channel blocker (CCB), and hydralazine, a peripheral direct vasodilator.
The possible associations between MA, several low-grade inflammation factors and LVH may provide a new insight into the pathophysiologic mechanisms of the CRS linking early renal impairment with elevated cardiovascular risk.

\section{Materials and Methods}

The protocols in the present study were designed according to the Guiding Principles in the Care and Use of Animals approved by the Council of the American Physiological Society and were in adherence to the Guide for the Care and Use of Laboratory Animals published by the US National Institutes of Health (NIH Publication no. 85-23, revised 1996).

\section{Animal model}

The rats (male, 220-250 g) were obtained from the "Centre d'Elevage R. Janvier" (Le Genest-Saint Isle, France) and were housed in individual metabolic cages. The $2 \mathrm{~K}-1 \mathrm{C}$ model and parameters collection used in this study were previously described (Saliba et al. 2010). Briefly, 2K-1C animals were the untreated animals that underwent the two kidney-one clip surgery to induce hypertension, while control rats were the un-operated un-treated animals. Drugs were administered to the three $2 \mathrm{~K}-1 \mathrm{C}$ operated groups daily by gavage to assure a $10 \mathrm{mg} / \mathrm{kg} /$ day consumption of amlodipine (Amlor: Pfizer, USA) a calcium channel blocker (CCB), and losartan (Cozaar: Merck, Netherlands) an angiotensin receptor blocker (ARB), and a $1 \mathrm{mg} / \mathrm{kg} /$ day consumption of Hydralazine hydrochloride (Apresolin: Novartis, Switzerland), a direct peripheral vasodilator. Systolic blood pressure (SBP) was measured once every two days, using the non-invasive tail-cuff method (Kubota et al. 2006).

One blood sample was weekly taken from the jugular vein of each rat, till the sacrifice. All plasma parameters measurements were done by the ELISA technique: TNF- $\alpha$ (Rat) kit (RayBiotech, USA), IL-6 (Rat) kit (RayBiotech, USA) and BNP-32 (Rat) kit (Peninsula Laboratories, Bachem Group, USA), TnT indirect ELISA was performed according to the protocol (Abcam, UK) using the monoclonal anti-TnT (Mouse) as primary antibody and polyclonal anti-Mouse IgG as secondary antibody. CRP-Slidex (bioMérieux, France) was used to detect the CRP semi quantitatively. Plasma creatinine measurement was based on the reaction of creatinine with alkaline picrate as described by Jaffé (Kit: 
Biolabo, Maizy, France). One 24 hour urine sample was weekly collected through the metabolic cages and the NycoCard U-ALBUMIN kit (Axis-Shield, Norway) was used to evaluate MA.

After 10 weeks, the rats were sacrificed, hearts were then excised and the ventricular cardiomyocytes were isolated, by the Langerdoff apparatus as previously described (Fares et al. 1996) and RNA was extracted from cells using Trizol reagent (Invitrogen life technologies, Carlsbad, CA, USA). The Real time PCR was performed using the SybrGreen PCR Master Mix (Applied Biosystems, Foster City, CA, USA) with the TATA binding protein (TBP) and Beta actin (ACTB) as housekeeping genes, to evaluate brain natriuretic pepide (BNP), alpha and beta myosin heavy chain ( $\alpha$ and $\beta$ MHC) mRNA levels.

Right kidneys were also taken from all groups $(n=24)$, fixed in formalin, then sectioned through their long axis into 2 slices, and embedded in paraffin. Fifteen sections of $3 \mu \mathrm{m}$ thick each were cut and stained with Hematoxylin-Eosin and examined by light microscopy. Gross examination and histological sections were analyzed by two independent pathologists in a blinded fashion, without knowledge as to how the animals were treated. A semi-quantitative scoring system was used to assess interstitial inflammation and tubular dilatation. Interstitial inflammation refers to the presence of aggregates of lymphocytes and neutrophils in the interstitium. Tubular dilatation was defined as a significant increase in luminal diameter (more than two folds), associated with flattening of the epithelial lining.

\section{Statistical analysis}

Statistical analysis was performed by the use of the one-way ANOVA for repeated measurements. The Mauchly's sphericity test was used to tell if the assumption of sphericity has been violated, then correction was performed by the Greenhouse-Geisser test. To explain the exact difference between group means, the post hoc Bonferroni test was applied. The relationships among the changes in MA, cardiac hypertrophy, plasma TNF- $\alpha$, plasma Il- $6, \beta-\mathrm{MHC}$ and BNP mRNA levels, before and after treatments were assessed by Spearman's correlation coefficient $\left(\mathrm{r}_{\mathrm{s}}\right)$. Results with $\mathrm{p}<0.05$ were considered statistically significant. All values are means \pm SEM.

\section{Results}

SBP, plasma TNF- $\alpha, I L-6, C R P$ and BNP levels

SBP significantly increased in the $2 \mathrm{~K}-1 \mathrm{C}$ group as compared to the control one $(172.5 \pm 3.4$ vs $110.7 \pm 2.9$ $\mathrm{mmHg}, p<0.001)$. SPB decreased in all 3 treated groups CCB (133.5 $\pm 4.0 \mathrm{mmHg}), \mathrm{ARB}(109.8 \pm 1.4 \mathrm{mmHg})$ and hydralazine $(124.3 \pm 1.9 \mathrm{mmHg})$ as compared to $2 \mathrm{~K}-1 \mathrm{C}$ rats $(p<0.001)$ (Figure 1-a).

As shown in Figure 1-b and 1-c respectively, plasma TNF- $\alpha$ and IL- 6 levels increased significantly in the $2 \mathrm{~K}-1 \mathrm{C}$ group as compared to the control one (TNF- $\alpha$ : $2.15 \pm 0.16$ vs $1.25 \pm 0.15 \mathrm{ng} / \mathrm{ml}, p<0.01$; IL-6: $1.475 \pm 0.22$ vs $1.095 \pm 0.17 \mathrm{ng} / \mathrm{ml}, p<0.001)$. Significant decreases were noted in TNF- $\alpha$ under CCB $(1.79 \pm 0.21 \mathrm{ng} / \mathrm{ml}), \mathrm{ARB}$ $(1.27 \pm 0.28 \mathrm{ng} / \mathrm{ml})$ and hydralazine $(0.85 \pm 0.35 \mathrm{ng} / \mathrm{ml})$ treatments $(p<0.001)$. Similar improvements were observed in IL-6 under CCB, ARB and hydralazine $(1.40 \pm 0.01,1.22 \pm 0.1$ and $0.88 \pm 0.1 \mathrm{ng} / \mathrm{ml}$ respectively, $p<0.001)$.

The semi quantitative CRP test showed an increase in CRP level in the $2 \mathrm{~K}-1 \mathrm{C}$ group with a value range of 7 to $20 \mathrm{mg} / \mathrm{l}$ (according to the kit datasheet); while normal values $(<7 \mathrm{mg} / \mathrm{l})$ were obtained under the different treatments and in the control group.

Furthermore, plasma BNP concentration increased in the $2 \mathrm{~K}-1 \mathrm{C}$ untreated rats $(2 \mathrm{~K}-1 \mathrm{C}: 1.96 \pm 0.02$ $\mathrm{ng} / \mathrm{ml} \quad v s$ control $0.33 \pm 0.09 \mathrm{ng} / \mathrm{ml}, \quad p<0.001)$, with diminished values under different treatments $(0.43 \pm 0.11$, $0.33 \pm 0.1$ and $0.54 \pm 0.26 \mathrm{ng} / \mathrm{ml}$ for $\mathrm{CCB}, \mathrm{ARB}$ and hydralazine respectively, $p<0.001$ ) (Figure 1-d).

\section{Urinary albumin and plasma creatinine levels}

$2 \mathrm{~K}-1 \mathrm{C}$ rats presented a MA with increased urinary albumin levels as compared to the control rats $(18 \pm 0.2$ vs $0.36 \pm 0.01 \mathrm{mg} / \mathrm{l} ; p<0.001)$. Low urinary albumin levels were observed for all treated groups $(0.07 \pm 0.01 \mathrm{mg} / 1, p<0.001)$ (Figure 1-e). Moreover, an increased plasma creatinine was also observed in the $2 \mathrm{~K}$ $1 \mathrm{C}$ group versus control $(0.8 \pm 0.11 \mathrm{mg} / \mathrm{dl}$ vs $0.7 \pm 0.01$ $\mathrm{mg} / \mathrm{dl} ; p<0.001)$. Decreases in creatinine were observed in the three treated groups (CCB: $0.74 \pm 0.01 \mathrm{mg} / \mathrm{dl}, \mathrm{ARB}$ : $0.69 \pm 0.01 \mathrm{mg} / \mathrm{dl}$ and hydralazine: $0.75 \pm 0.1, p<0.05$ ) (Figure 1-f).

\section{LVH and renal function assessment}

An increase in the cardiac mass was observed in the $2 \mathrm{~K}-1 \mathrm{C}$ group in comparison with control rats, as evaluated by heart weight over body weight (HW/BW) 
and heart weight over tibia length (HW/TL) ratios $(5.41 \pm 0.07$ vs $3.6 \pm 0.08 \mathrm{mg} / \mathrm{g}, p<0.05$ and $420.17 \pm 15.67$ vs $290.26 \pm 8.23 \mathrm{mg} / \mathrm{cm}, p<0.05$ respectively). Decreases in cardiac mass were noted under treatments, as assessed by $\mathrm{HW} / \mathrm{BW}$ (CCB: 5.12 \pm 0.09 , ARB: $4.64 \pm 0.29$ and hydralazine: $4.6 \pm 0.27 \mathrm{mg} / \mathrm{g}, p<0.05$ ) and HW/TL (CCB: $388.85 \pm 11.83$, ARB: $297.41 \pm 6.61$ and hydralazine: $317.69 \pm 20.83 \mathrm{mg} / \mathrm{cm}, p<0.05$ ) (Figure 1g-h).
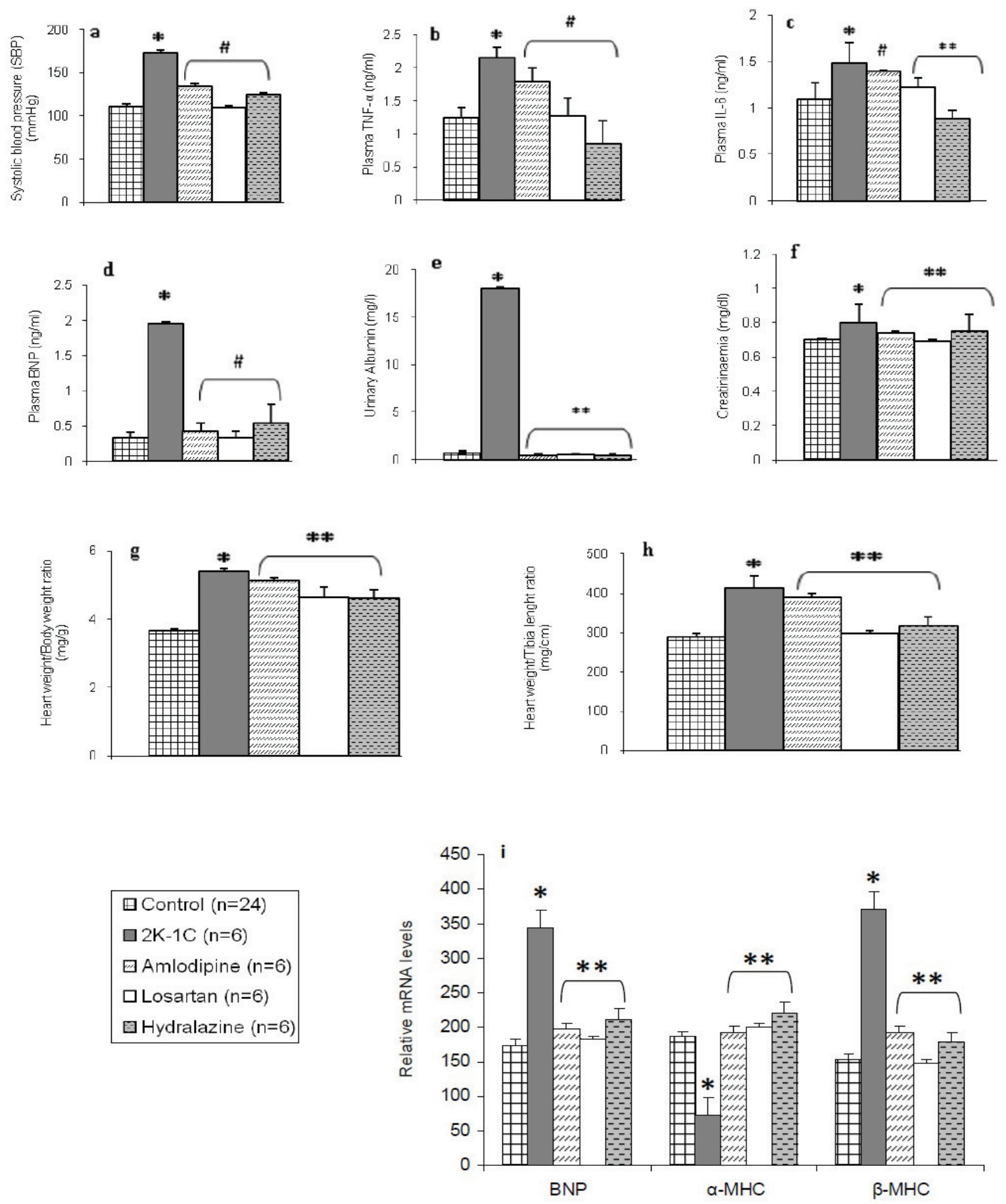

Fig. 1. $S B P$, inflammatory markers, $B N P$, urinary albumin, creatininaemia and cardiac mass variations in the treated and untreated rats, along with the gene expression variation of BNP, a-MHC and $\beta-M H C$ and histological changes analysis. a) SBP: $*$ p $<0.001$ vs Control, \# $\mathrm{p}<0.001$ vs 2K-1C; b) Plasma TNF-a: * $\mathrm{p}<0.01$ vs Control, \# $\mathrm{p}<0.001$ vs $2 \mathrm{~K}-1 \mathrm{C}$; c) Plasma IL-6: * $\mathrm{p}<0.05$ vs Control, $* * \mathrm{p}<0.001$ vs 2K-1C, \# $\mathrm{p}<0.05$ vs 2K-1C; d) Plasma BNP: * $\mathrm{p}<0.01$ vs Control, \# $\mathrm{p}<0.001$ vs $2 \mathrm{~K}-1 \mathrm{C}$; e) Urinary albumin: * $\mathrm{p}<0.001$ vs Control, $* * \mathrm{p}<0.001$ vs $2 \mathrm{~K}-1 \mathrm{C} ;$ f) Creatininaemia: $* \mathrm{p}<0.05$ vs Control, $* * \mathrm{p}<0.05$ vs $2 \mathrm{~K}-1 \mathrm{C} ; \mathbf{g})$ Heart weight/Body weight ratio: $* \mathrm{p}<0.001$ vs Control, ** $\mathrm{p}<0.05$ vs $2 \mathrm{~K}-1 \mathrm{C}$; h) Heart weight/Tibia length ratio: $* \mathrm{p}<0.001$ vs Control, $* * \mathrm{p}<0.05$ vs $2 \mathrm{~K}-1 \mathrm{C} ; \mathrm{i}) \mathrm{BNP}$, alpha- and betaMHC mRNA levels: * $\mathrm{p}<0.001$ vs Control, $* * \mathrm{p}<0.05$ vs $2 \mathrm{~K}-1 \mathrm{C}$. SBP: systolic blood pressure, TNF-a: tumor necrosis factor $\mathrm{a}$, IL-6: interleukin 6, BNP: brain natriuretic peptide, MHC: myosin heavy chain. Data are presented as mean \pm SEM; n: number of animals. 
Table 1. A semi-quantitative scoring system was used to assess interstitial inflammation and tubular dilation: - for no damage, \pm for minimal damage with rare and small foci, + for mild damage with few and small foci and ++ for moderate damage with frequent and moderately sized foci, R.K. for Right Kidney.

\section{R.K. 2K-1C R.K. Amlodipine $\quad$ R.K. Losartan $\quad$ R.K. Hydralazine}

\begin{tabular}{|c|c|c|c|c|c|}
\hline Tubule & Dilation & \pm & \pm & - & - \\
\hline Interstitium & Inflammation & ++ & + & + & + \\
\hline
\end{tabular}

Cardiac Troponin $\mathrm{T}$, a marker of myocardial ischemia, showed no significant elevation in any of the groups (data not shown).

BNP gene expression increased in the $2 \mathrm{~K}-1 \mathrm{C}$ group in comparison with control group (174 \pm 8 vs $345 \pm 24.5 \%, p<0.001)$ while a decrease was observed in all treated groups as compared $(2 \mathrm{~K}-1 \mathrm{C}$ : $345 \pm 24.5$ vs CCB: $198 \pm 8.5$, ARB: $182 \pm 5.5$ and hydralazine: $212 \pm 14 \%$ respectively, $p<0.05$ ). Simultaneous decrease in $\beta-\mathrm{MHC}$ (2K-1C: $372 \pm 17 \%$ vs CCB: $186 \pm 24$, ARB: $178 \pm 6$ and hydralazine: $148 \pm 18 \%, p<0.05$ ) and increase in $\alpha$-MHC expression $(2 \mathrm{~K}-1 \mathrm{C}$ : $74 \pm 7.5$ vs CCB: $193 \pm 8$, ARB: $200 \pm 13$ and hydralazine: $222 \pm 18 \%, p<0.05$ ) were noted under the different treatments concurring with normal $\beta$-MHC and $\alpha$-MHC expression levels $(153 \pm 11.5$ and $186 \pm 14 \%$ respectively; Figure 1-i).

Renal histological sections analysis showed the reduction of tubular dilation and interstitial inflammation after different treatments (Table 1).

Correlation of MA with inflammatory markers and LVH

A significant correlation was found between MA and several inflammatory factor (TNF- $\alpha: r_{s}=0.95$ and IL-6: $r_{\mathrm{s}}=0.876$ ) as well as LVH markers (BNP mRNA: $r_{s}=0.86$ and $\beta$-MHC: $r_{s}=0.92$ ).

\section{Discussion}

CRP has emerged as one of the most powerful independent predictors of risk for CVD. Plasma CRP level is an independent risk factor for the development of LVH among children with essential hypertension (Assadi 2008). While augmented CRP concentrations in subjects with normal blood pressure are associated with development of hypertension, they are also involved in unfavorable adaptations of left ventricular geometry in patients who already have hypertension without LVH (Sesso et al. 2003, Tsioufis et al. 2005). A pathogenic role of human CRP in pressure overload-induced cardiac remodeling and in metabolic syndrome has been recently shown (Nagai et al. 2011, Pravenec et al. 2011). In our study, CRP was only present in the $2 \mathrm{~K}-1 \mathrm{C}$ rats that developed the most marked cardiac hypertrophy and increased SBP, while the treatment with either RAAS interfering or non-interfering blood pressure lowering drugs eliminated the presence of CRP.

The mechanism of the relation between CRP and progressive CVD is assumed to be based on a low-grade inflammatory state either originating in the vasculature or a systemic effect on the vasculature due to inflammatory mediators released elsewhere in the body, e.g. adipose tissue, or due to external stimuli, e.g. smoking. This inflammation results in endothelial dysfunction and impaired vasoreactivity by inhibiting endothelial nitric oxide synthase, increasing prostacyclin production, activating RAAS and producing reactive oxygen species (Basi and Lewis 2006, Guan et al. 2009, Verma et al. 2002b, Wang et al. 2003). CRP also promotes proinflammatory cytokine production leading to mesangial cell proliferation, matrix overproduction and increased vascular permeability resulting in MA (Pai et al. 2004, Verma et al. 2002a).

Other inflammatory components such TNF- $\alpha$, IL-1 $\beta$ and IL-6 also have important implications in CVD (Navarro-Gonzalez et al. 2008, Peeters et al. 2001, Tzoulaki et al. 2005). Serum IL-6 is a powerful independent predictor of future $\mathrm{CV}$ events with a prognostic value superior to that of CRP (Nishida et al. 2011). Several studies have shown that elevated levels of IL-6 are associated with increased risk of the progression of atherosclerotic lesions and future cardiovascular events (Fisman et al. 2006, Tzoulaki et al. 2005, Welsh et al. 2008). While some found that in newly diagnosed essentially hypertensive patients, UAE is independently associated with urinary but not plasma TNF- $\alpha$ (NavarroGonzalez et al. 2008), we found a correlation between the presence of MA and plasma TNF- $\alpha$ in the hypertensive rats with or without treatment. Our results are in agreement with previous works where they demonstrated that coronary endothelial dysfunction is associated with 
an elevation of plasma TNF- $\alpha$ in patients with essential hypertension (Naya et al. 2007). These different results could be explained by the differences between the patients or animal models in question; thus, newly or established hypertension must be taken into consideration, as well as the presence or not of $\mathrm{LVH}$, in the assessment of different inflammatory processes. Similarly, MA is accompanied by increased levels of CRP but not augmented interleukin 18 and soluble CD40 ligand concentrations in essential hypertensive patients (Tsioufis et al. 2006); indeed, we have found that MA presence correlated with CRP, IL-6 and TNF- $\alpha$ concentrations, supporting the notion of the activation of different inflammatory pathways in the progression of this renal and cardiovascular atherosclerotic disease, the CRS.

MA appearance in the urine not only reflects early vascular or glomerular disease in the kidney, but also indicates early vascular or endothelial glycocalyx damage in the vascular tree in general (Clausen et al. 2001, Haraldsson et al. 2008). On one hand, MA is considered as a "biomarker" of adverse outcomes, even among subjects with normal or nearly normal renal function (Hallan et al. 2009, Hemmelgarn et al. 2010, James et al. 2010); on the other, several retrospective studies have reported that the prevalence of CVD is significantly higher among adult hypertensive patients with MA than hypertensive patients without MA (Knight et al. 2003). MA-lowering therapy can also halt the progression of LVH or induce its regression in hypertensive children and adolescents in a manner largely independent of blood pressure control (Assadi 2007). Our work showed that MA was accompanied by increased cardiac stress plasma markers such as BNP levels, a marked LVH as shown by HW/BW and HW/TL ratios as well as the standard hypertrophy molecular markers (BNP, $\alpha$ and $\beta$-MHC cardiomyocytes' mRNA levels). Renal function loss was also noted by the increase in creatininaemia, tubular dilation and interstitial inflammation.

MA may lead to heart failure via several pathways, including direct myocardial pathology, as well as development of insulin resistance/diabetes and hypertension (Brantsma et al. 2006, Brantsma et al. 2005). MA increases the risk of heart failure despite aggressive blood pressure lowering treatment in both diabetic and non-diabetic individuals (De Zeeuw et al. 2004, Okinet al. 2008). MA is an independent marker of morbidity and mortality in patients (both diabetic and non-diabetic) who have experienced acute myocardial infarction (Berton et al. 2008, Sukhija et al. 2006).

In addition, observations in the Framingham Heart Study cohort have nicely shown that a subtle increase in UAE antedates the clinical outset of arterial hypertension in healthy individuals in the general population (Wang et al. 2005). A positive association between MA, LV mass and wall thickness in normotensive and hypertensive adults has been found (Djousse et al. 2008). MA may also be associated with early structural changes in myocardium that have not yet affected left ventricular function (Arnlov et al. 2005). Incremental increase in MA, even within the normal range is associated with an increased rate of cardiovascular events in adults (Forman et al. 2008, Matsushita et al. 2010). Therefore, the progression of blood pressure from "pre-hypertension" to frank hypertension can be delayed by drug therapy (Julius et al. 2006), and screening for MA may identify a subgroup of patients who are at high risk for developing CVD and could benefit from early therapy and closer follow-up. Treatment with RAAS inhibitors lowers MA and lowers heart failure onset, as well as cardiovascular risk in general (Ibsen et al. 2005, Ibsen et al. 2006). In our 2K$1 \mathrm{C}$ rat model, treatments with an ARB as well as CCB and hydralazine led to the absence of MA parallel to a decrease in SBP, cardiac stress and hypertrophy markers, as well as a regain in renal function as assessed by lower plasma creatinine, and improved kidney histology.

Studies have shown that CRP is associated with MA in the general population (Kshirsagar et al. 2008, Nakamura et al. 2004). Elevated CRP levels are associated with MA independent of diabetes, hypertension and other potential confounders (Sabanayagam et al. 2010). Hypertensive children and adolescents with LVH have higher MA and CRP levels compared with those of children without LVH (Assadi 2008). An association between CRP and LVH was observed only in the subgroup with normal UAE, suggesting that systemic low-grade inflammation might precede endothelial dysfunction/damage (Salles et al. 2007). This lack of association of MA and CRP has been reported by some (Palmieri et al. 2003, Perticone et al. 2007) but not by other investigators (Tsioufis et al. 2005), and has also been suggested that their association may be influenced by blood pressure levels, being positive only in hypertensive subjects (Stuveling et al. 2004). In our $2 \mathrm{~K}-1 \mathrm{C}$ model, LVH was within an initial compensated stage following an acute rise of RAAS 
where CRP and MA could be present and acting at the same time promoting LVH.

The influence of antihypertensive medication on inflammation is an interesting, yet not well known aspect of blood pressure-lowering medication. Different drugs exert anti-inflammatory effects in addition to their antihypertensive properties, with improvement of cardiovascular outcome by reducing vascular inflammation and remodeling (Savoia and Schiffrin 2007). Treatment with ARBs is as effective as angiotensin converting enzyme inhibitors (ACEi) in reducing proteinuria, and the combination of both was more effective than either drug alone (Kunz et al. 2008). Both ACEi and ARBs are recommended, either as monotherapy or in combination with other agents (Mancia et al. 2007). Several studies tried to answer the question of whether treatment with an ACEi or an ARB can prevent the development of MA in normo-albuminuric patients. Though the Diabetic Retinopathy Candesartan Trials 1 and 2, and Renin Angiotensin System Study (RASS) showed no benefit in MA prevention (Bilous et al. 2009, Mauer et al. 2009), the Randomized Olmesartan And Diabetes MicroAlbuminuria Prevention study (ROADMAP trial) showed that the ARB olmesartan was associated with a delayed onset of MA in type 2 diabetes patients (Haller et al. 2011). One could suggest that administration of antihypertensive therapy with pleiotropic effects beyond decreasing blood pressure (i.e. ACEi, ARBs and so forth) could be of clinical importance not only in the setting of complicated hypertension but also in the early stages of the CRS disease.

It also should be noted that other unconventional treatments with anti-inflammatory actions are being studied for their effects on the cardiovascular system. In fact, the TNF- $\alpha$ antagonist etanercept has been shown to decrease blood pressure, protect the kidney and prevent the development of hypertension in rat models (Tran et al. 2009, Venegas-Pont et al. 2010). Further investigations need be conducted to confirm the efficiency of this treatment, since others have found that etanercept treatment in spontaneously hypertensive rats resulted in an up-regulation of IL-6 (Haugen et al. 2008).

In the vicious circle connecting essential hypertension, microalbuminuric state, and atherosclerotic cardiovascular events, apart from the mainstay role of the RAAS and endothelial dysfunction, subclinical inflammation participates through different pathways to all stages of this deleterious process. Monitoring and controlling MA and CRP should be important strategies in order to reduce the risk of cardiovascular events even in the seemingly normal population. In this study, we showed a correlation between the decrease of MA and other inflammatory components suggesting an important role of MA-inflammation lowering therapy in protecting against cardiac hypertrophy and renal injury. Further investigations need to be done on the same $2 \mathrm{~K}-1 \mathrm{C}$ rat model but on an extended period of treatments, with or without pre-operative drug initiation, in order to dissect the relationship between MA and inflammation, whether they can be separated as risk factors or not within the CRS.

\section{Conflict of Interest}

There is no conflict of interest.

\section{Acknowledgements}

This work was supported by the Research Council of the Saint Joseph University - Faculty of Medicine.

\section{References}

ARNLOV J, EVANS JC, MEIGS JB, WANG TJ, FOX CS, LEVY D, BENJAMIN EJ, D'AGOSTINO RB, VASAN RS: Low-grade albuminuria and incidence of cardiovascular disease events in nonhypertensive and nondiabetic individuals: the Framingham Heart Study. Circulation 112: 969-975, 2005.

ASSADI F: Effect of microalbuminuria lowering on regression of left ventricular hypertrophy in children and adolescents with essential hypertension. Pediatr Cardiol 28: 27-33, 2007.

ASSADI F: Relation of left ventricular hypertrophy to microalbuminuria and C-reactive protein in children and adolescents with essential hypertension. Pediatr Cardiol 29: 580-584, 2008.

BAHRAMI H, BLUEMKE DA, KRONMAL R, BERTONI AG, LLOYD-JONES DM, SHAHAR E, SZKLO M, LIMA JA: Novel metabolic risk factors for incident heart failure and their relationship with obesity: the MESA (Multi-Ethnic Study of Atherosclerosis) study. J Am Coll Cardiol 51: 1775-1783, 2008.

BASI S, LEWIS JB: Microalbuminuria as a target to improve cardiovascular and renal outcomes. Am J Kidney Dis 47: 927-946, 2006. 
BAUTISTA LE, VERA LM, ARENAS IA, GAMARRA G: Independent association between inflammatory markers (C-reactive protein, interleukin-6, and TNF-alpha) and essential hypertension. J Hum Hypertens 19: 149-154, 2005.

BERTON G, CORDIANO R, MAZZUCO S, KATZ E, DE TONI R, PALATINI P: Albumin excretion in acute myocardial infarction: a guide for long-term prognosis. Am Heart J 156: 760-768, 2008.

BILOUS R, CHATURVEDI N, SJOLIE AK, FULLER J, KLEIN R, ORCHARD T, PORTA M, PARVING HH: Effect of candesartan on microalbuminuria and albumin excretion rate in diabetes: three randomized trials. Ann Intern Med 151: 11-20, W3-W4, 2009.

BLAKE GJ, RIDKER PM: C-reactive protein and other inflammatory risk markers in acute coronary syndromes. $J \mathrm{Am}$ Coll Cardiol 41: 37S-42S, 2003.

BRANTSMA AH, BAKKER SJ, DE ZEEUW D, DE JONG PE, GANSEVOORT RT: Urinary albumin excretion as a predictor of the development of hypertension in the general population. J Am Soc Nephrol 17: 331-335, 2006.

BRANTSMA AH, BAKKER SJ, HILLEGE HL, DE ZEEUW D, DE JONG PE, GANSEVOORT RT: Urinary albumin excretion and its relation with $\mathrm{C}$-reactive protein and the metabolic syndrome in the prediction of type 2 diabetes. Diabetes Care 28: 2525-2530, 2005.

CARR AA, KOWEY PR, DEVEREUX RB, BRENNER BM, DAHLOF B, IBSEN H, LINDHOLM LH, LYLE PA, SNAPINN SM, ZHANG Z, EDELMAN JM, SHAHINFAR S: Hospitalizations for new heart failure among subjects with diabetes mellitus in the RENAAL and LIFE studies. Am J Cardiol 96: 1530-1536, 2005.

CLAUSEN P, JENSEN JS, JENSEN G, BORCH-JOHNSEN K, FELDT-RASMUSSEN B: Elevated urinary albumin excretion is associated with impaired arterial dilatory capacity in clinically healthy subjects. Circulation 103: 1869-1874, 2001.

DE ZEEUW D, PARVING HH, HENNING RH: Microalbuminuria as an early marker for cardiovascular disease. $J A m$ Soc Nephrol 17: 2100-2105, 2006.

DE ZEEUW D, REMUZZI G, PARVING HH, KEANE WF, ZHANG Z, SHAHINFAR S, SNAPINN S, COOPER ME, MITCH WE, BRENNER BM: Albuminuria, a therapeutic target for cardiovascular protection in type 2 diabetic patients with nephropathy. Circulation 110: 921-927, 2004.

DJOUSSE L, KOCHAR J, HUNT SC, NORTH KE, GU CC, TANG W, ARNETT DK, DEVEREUX RB: Relation of albuminuria to left ventricular mass (from the HyperGEN Study). Am J Cardiol 101: 212-216, 2008.

FARES N, GOMEZ JP, POTREAU D: T-type calcium current is expressed in dedifferentiated adult rat ventricular cells in primary culture. C R Acad Sci III 319: 569-576, 1996.

FESTA A, D'AGOSTINO R, HOWARD G, MYKKANEN L, TRACY RP, HAFFNER SM: Inflammation and microalbuminuria in nondiabetic and type 2 diabetic subjects: The Insulin Resistance Atherosclerosis Study. Kidney Int 58: 1703-1710, 2000.

FISMAN EZ, BENDERLY M, ESPER RJ, BEHAR S, BOYKO V, ADLER Y, TANNE D, MATAS Z, TENENBAUM A: Interleukin-6 and the risk of future cardiovascular events in patients with angina pectoris and/or healed myocardial infarction. Am J Cardiol 98: 14-18, 2006.

FORMAN JP, FISHER ND, SCHOPICK EL, CURHAN GC: Higher levels of albuminuria within the normal range predict incident hypertension. J Am Soc Nephrol 19: 1983-1988, 2008.

GUAN H, WANG P, HUI R, EDIN ML, ZELDIN DC, WANG DW: Adeno-associated virus-mediated human Creactive protein gene delivery causes endothelial dysfunction and hypertension in rats. Clin Chem 55: 274-284, 2009.

HALLAN SI, RITZ E, LYDERSEN S, ROMUNDSTAD S, KVENILD K, ORTH SR: Combining GFR and albuminuria to classify CKD improves prediction of ESRD. J Am Soc Nephrol 20: 1069-1077, 2009.

HALLER H, ITO S, IZZO JL Jr, JANUSZEWICZ A, KATAYAMA S, MENNE J, MIMRAN A, RABELINK TJ, RITZ E, RUILOPE LM, RUMP LC, VIBERTI G: Olmesartan for the delay or prevention of microalbuminuria in type 2 diabetes. $N$ Engl J Med 364: 907-917, 2011.

HARALDSSON B, NYSTROM J, DEEN WM: Properties of the glomerular barrier and mechanisms of proteinuria. Physiol Rev 88: 451-487, 2008.

HAUGEN E, TANG MS, ISIC A, ANDERSSON B, FU M: TNFalpha antagonist upregulates interleukin-6 in rats with hypertensive heart failure. Int J Cardiol 130: 64-68, 2008. 
HEMMELGARN BR, MANNS BJ, LLOYD A, JAMES MT, KLARENBACH S, QUINN RR, WIEBE N, TONELLI M: Relation between kidney function, proteinuria, and adverse outcomes. JAMA 303: 423-429, 2010.

HEYWOOD JT: The cardiorenal syndrome: lessons from the ADHERE database and treatment options. Heart Fail Rev 9: 195-201, 2004.

IBSEN H, OLSEN MH, WACHTELL K, BORCH-JOHNSEN K, LINDHOLM LH, MOGENSEN CE, DAHLOF B, DEVEREUX RB, DE FAIRE U, FYHRQUIST F, JULIUS S, KJELDSEN SE, LEDERBALLE-PEDERSEN O, NIEMINEN MS, OMVIK P, OPARIL S, WAN Y: Reduction in albuminuria translates to reduction in cardiovascular events in hypertensive patients: losartan intervention for endpoint reduction in hypertension study. Hypertension 45: 198-202, 2005.

IBSEN H, OLSEN MH, WACHTELL K, BORCH-JOHNSEN K, LINDHOLM LH, MOGENSEN CE, DAHLOF B, SNAPINN SM, WAN Y, LYLE PA: Does albuminuria predict cardiovascular outcomes on treatment with losartan versus atenolol in patients with diabetes, hypertension, and left ventricular hypertrophy? The LIFE study. Diabetes Care 29: 595-600, 2006.

INGELSSON E, SUNDSTROM J, LIND L, RISERUS U, LARSSON A, BASU S, ARNLOV J: Low-grade albuminuria and the incidence of heart failure in a community-based cohort of elderly men. Eur Heart $J \mathbf{2 8}$ : 1739-1745, 2007.

JAMES MT, HEMMELGARN BR, TONELLI M: Early recognition and prevention of chronic kidney disease. Lancet 375: 1296-1309, 2010.

JULIUS S, NESBITT SD, EGAN BM, WEBER MA, MICHELSON EL, KACIROTI N, BLACK HR, GRIMM RH Jr, MESSERLI FH, OPARIL S, SCHORK MA: Feasibility of treating prehypertension with an angiotensinreceptor blocker. $N$ Engl J Med 354: 1685-1697, 2006.

KAPTOGE S, Di ANGELANTONIO E, LOWE G, PEPYS MB, THOMPSON SG, COLLINS R, DANESH J: C-reactive protein concentration and risk of coronary heart disease, stroke, and mortality: an individual participant meta-analysis. Lancet 375: 132-140, 2010.

KISTORP C, RAYMOND I, PEDERSEN F, GUSTAFSSON F, FABER J, HILDEBRANDT P: N-terminal pro-brain natriuretic peptide, C-reactive protein, and urinary albumin levels as predictors of mortality and cardiovascular events in older adults. JAMA 293: 1609-1616, 2005.

KNIGHT EL, KRAMER HM, CURHAN GC: High-normal blood pressure and microalbuminuria. Am J Kidney Dis 41: 588-595, 2003.

KSHIRSAGAR AV, BOMBACK AS, BANG H, GERBER LM, VUPPUTURI S, SHOHAM DA, MAZUMDAR M, BALLANTYNE CM, PAPARELLO JJ, KLEMMER PJ: Association of C-reactive protein and microalbuminuria (from the National Health and Nutrition Examination Surveys, 1999 to 2004). Am J Cardiol 101: 401-406, 2008.

KUBOTA Y, UMEGAKI K, KAGOTA S, TANAKA N, NAKAMURA K, KUNITOMO M, SHINOZUKA K: Evaluation of blood pressure measured by tail-cuff methods (without heating) in spontaneously hypertensive rats. Biol Pharm Bull 29: 1756-1758, 2006.

KUNZ R, FRIEDRICH C, WOLBERS M, MANN JF: Meta-analysis: effect of monotherapy and combination therapy with inhibitors of the renin angiotensin system on proteinuria in renal disease. Ann Intern Med 148: 30-48, 2008.

MANCIA G, DE BACKER G, DOMINICZAK A, CIFKOVA R, FAGARD R, GERMANO G, GRASSI G, HEAGERTY AM, KJELDSEN SE, LAURENT S, NARKIEWICZ K, RUILOPE L, RYNKIEWICZ A, SCHMIEDER RE, BOUDIER HA, ZANCHETTI A, VAHANIAN A, CAMM J, DE CATERINA R, DEAN V, DICKSTEIN K, FILIPPATOS G, FUNCK-BRENTANO C, HELLEMANS I, KRISTENSEN SD, MCGREGOR K, SECHTEM U, SILBER S, TENDERA M, WIDIMSKY P, ZAMORANO JL, ERDINE S, KIOWSKI W, AGABITI-ROSEI E, AMBROSIONI E, LINDHOLM LH, VIIGIMAA M, ADAMOPOULOS S, BERTOMEU V, CLEMENT D, FARSANG C, GAITA D, LIP G, MALLION JM, MANOLIS AJ, NILSSON PM, O'BRIEN E, PONIKOWSKI P, REDON J, RUSCHITZKA F, TAMARGO J, VAN ZWIETEN P, WAEBER B, WILLIAMS B: 2007 Guidelines for the Management of Arterial Hypertension: The Task Force for the Management of Arterial Hypertension of the European Society of Hypertension (ESH) and of the European Society of Cardiology (ESC). J Hypertens 25: 1105-1187, 2007. 
MARCOVECCHIO ML, GIANNINI C, WIDMER B, DALTON RN, MARTINOTTI S, CHIARELLI F, DUNGER DB: C-reactive protein in relation to the development of microalbuminuria in type 1 diabetes: the Oxford Regional Prospective Study. Diabetes Care 31: 974-976, 2008.

MATSUSHITA K, VAN DER VELDE M, ASTOR BC, WOODWARD M, LEVEY AS, DE JONG PE, CORESH J, GANSEVOORT RT: Association of estimated glomerular filtration rate and albuminuria with all-cause and cardiovascular mortality in general population cohorts: a collaborative meta-analysis. Lancet 375: 2073-2081, 2010.

MAUER M, ZINMAN B, GARDINER R, SUISSA S, SINAIKO A, STRAND T, DRUMMOND K, DONNELLY S, GOODYER P, GUBLER MC, KLEIN R: Renal and retinal effects of enalapril and losartan in type 1 diabetes. N Engl J Med 361: 40-51, 2009.

NAGAI T, ANZAI T, KANEKO H, MANO Y, ANZAI A, MAEKAWA Y, TAKAHASHI T, MEGURO T, YOSHIKAWA T, FUKUDA K: C-reactive protein overexpression exacerbates pressure overload-induced cardiac remodeling through enhanced inflammatory response. Hypertension 57: 208-215, 2011.

NAKAMURA M, ONODA T, ITAI K, OHSAWA M, SATOU K, SAKAI T, SEGAWA T, SASAKI J, TONARI Y, HIRAMORI K, OKAYAMA A: Association between serum C-reactive protein levels and microalbuminuria: a population-based cross-sectional study in northern Iwate, Japan. Intern Med 43: 919-925, 2004.

NAVARRO-GONZALEZ JF, MORA C, MUROS M, JARQUE A, HERRERA H, GARCIA J: Association of tumor necrosis factor-alpha with early target organ damage in newly diagnosed patients with essential hypertension. J Hypertens 26: 2168-2175, 2008.

NAYA M, TSUKAMOTO T, MORITA K, KATOH C, FURUMOTO T, FUJII S, TAMAKI N, TSUTSUI H: Plasma interleukin-6 and tumor necrosis factor-alpha can predict coronary endothelial dysfunction in hypertensive patients. Hypertens Res 30: 541-548, 2007.

NISHIDA H, HORIO T, SUZUKI Y, IWASHIMA Y, TOKUDOME T, YOSHIHARA F, NAKAMURA S, KAWANO Y: Interleukin-6 as an independent predictor of future cardiovascular events in high-risk Japanese patients: comparison with C-reactive protein. Cytokine 53: 342-346, 2011.

OKIN PM, WACHTELL K, DEVEREUX RB, NIEMINEN MS, OIKARINEN L, VIITASALO M, TOIVONEN L, IBSEN H, OLSEN MH, BORCH-JOHNSEN K, LINDHOLM LH, KJELDSEN SE, JULIUS S, DAHLOF B: Combination of the electrocardiographic strain pattern and albuminuria for the prediction of new-onset heart failure in hypertensive patients: the LIFE study. Am J Hypertens 21: 273-279, 2008.

PAI JK, PISCHON T, MA J, MANSON JE, HANKINSON SE, JOSHIPURA K, CURHAN GC, RIFAI N, CANNUSCIO CC, STAMPFER MJ, RIMM EB: Inflammatory markers and the risk of coronary heart disease in men and women. $N$ Engl J Med 351: 2599-2610, 2004.

PALMIERI V, TRACY RP, ROMAN MJ, LIU JE, BEST LG, BELLA JN, ROBBINS DC, HOWARD BV, DEVEREUX RB: Relation of left ventricular hypertrophy to inflammation and albuminuria in adults with type 2 diabetes: the strong heart study. Diabetes Care 26: 2764-2769, 2003.

PARVING HH, LEWIS JB, RAVID M, REMUZZI G, HUNSICKER LG: Prevalence and risk factors for microalbuminuria in a referred cohort of type II diabetic patients: a global perspective. Kidney Int 69: 20572063, 2006.

PEDRINElli R, Dell'OMO G, Di Bello V, PEllegrini G, PUCCI L, Del PRATO S, PENNO G: Low-grade inflammation and microalbuminuria in hypertension. Arterioscler Thromb Vasc Biol 24: 2414-2419, 2004.

PEETERS AC, NETEA MG, JANSSEN MC, KULLBERG BJ, VAN DER MEER JW, THIEN T: Pro-inflammatory cytokines in patients with essential hypertension. Eur J Clin Invest 31: 31-36, 2001.

PERTICONE F, MAIO R, TRIPEPI G, SCIACQUA A, MALLAMACI F, ZOCCALI C: Microalbuminuria, endothelial dysfunction and inflammation in primary hypertension. J Nephrol 20 (Suppl 12): S56-S62, 2007.

PRAVENEC M, KAJIYA T, ZIDEK V, LANDA V, MLEJNEK P, SIMAKOVA M, SILHAVY J, MALINSKA H, OLIYARNYK O, KAZDOVA L, FAN J, WANG J, KURTZ TW: Effects of human C-reactive protein on pathogenesis of features of the metabolic syndrome. Hypertension 57: 731-737, 2011.

SABANAYAGAM C, LEE J, SHANKAR A, LIM SC, WONG TY, TAI ES: C-reactive protein and microalbuminuria in a multi-ethnic Asian population. Nephrol Dial Transplant 25: 1167-1172, 2010.

SALIBA Y, CHOUERY E, MEGARBANE A, JABBOUR H, FARES N: Microalbuminuria versus brain natriuretic peptide in cardiac hypertrophy of hypertensive rats. Physiol Res 59: 871-880, 2010. 
SALLES GF, FISZMAN R, CARDOSO CR, MUXFELDT ES: Relation of left ventricular hypertrophy with systemic inflammation and endothelial damage in resistant hypertension. Hypertension 50: 723-728, 2007.

SAVOIA C, SCHIFFRIN EL: Reduction of C-reactive protein and the use of anti-hypertensives. Vasc Health Risk Manag 3: 975-983, 2007.

SESSO HD, BURING JE, RIFAI N, BLAKE GJ, GAZIANO JM, RIDKER PM: C-reactive protein and the risk of developing hypertension. JAMA 290: 2945-2951, 2003.

STUVELING EM, BAKKER SJ, HILLEGE HL, BURGERHOF JG, DE JONG PE, GANS RO, DE ZEEUW D: C-reactive protein modifies the relationship between blood pressure and microalbuminuria. Hypertension 43 : 791-796, 2004.

SUKHIJA R, ARONOW WS, KAKAR P, GARZA L, SACHDEVA R, SINHA A, MEHTA JL: Relation of microalbuminuria and coronary artery disease in patients with and without diabetes mellitus. Am J Cardiol 98: 279-281, 2006.

TRAN LT, MACLEOD KM, MCNEILL JH: Chronic etanercept treatment prevents the development of hypertension in fructose-fed rats. Mol Cell Biochem 330: 219-228, 2009.

TSIOUFIS C, DIMITRIADIS K, CHATZIS D, VASILIADOU C, TOUSOULIS D, PAPADEMETRIOU V, TOUTOUZAS P, STEFANADIS C, KALLIKAZAROS I: Relation of microalbuminuria to adiponectin and augmented C-reactive protein levels in men with essential hypertension. Am J Cardiol 96: 946-951, 2005.

TSIOUFIS C, DIMITRIADIS K, STEFANADIS C, KALLIKAZAROS I: The emerging role of subclinical inflammation in hypertension-associated early renal dysfunction: focus on microalbuminuria. Hellenic $J$ Cardiol 47: 361-365, 2006.

TSIOUFIS C, DIMITRIADIS K, TAXIARCHOU E, VASILIADOU C, CHARTZOULAKIS G, TOUSOULIS D, MANOLIS A, STEFANADIS C, KALLIKAZAROS I: Diverse associations of microalbuminuria with Creactive protein, interleukin-18 and soluble CD 40 ligand in male essential hypertensive subjects. Am J Hypertens 19: 462-466, 2006.

TSIOUFIS C, STOUGIANNOS P, KAKKAVAS A, TOUTOUZA M, MARIOLIS A, VLASSEROS I, STEFANADIS C, KALLIKAZAROS I: Relation of left ventricular concentric remodeling to levels of C-reactive protein and serum amyloid A in patients with essential hypertension. Am J Cardiol 96: 252-256, 2005.

TZOULAKI I, MURRAY GD, LEE AJ, RUMLEY A, LOWE GD, FOWKES FG: C-reactive protein, interleukin-6, and soluble adhesion molecules as predictors of progressive peripheral atherosclerosis in the general population: Edinburgh Artery Study. Circulation 112: 976-983, 2005.

VAKILI BA, OKIN PM, DEVEREUX RB: Prognostic implications of left ventricular hypertrophy. Am Heart J 141: 334-341, 2001

VENEGAS-PONT M, MANIGRASSO MB, GRIFONI SC, LAMARCA BB, MARIC C, RACUSEN LC, GLOVER PH, JONES AV, DRUMMOND HA, RYAN MJ: Tumor necrosis factor-alpha antagonist etanercept decreases blood pressure and protects the kidney in a mouse model of systemic lupus erythematosus. Hypertension $\mathbf{5 6}$ : 643-649, 2010.

VERMA S, LI SH, BADIWALA MV, WEISEL RD, FEDAK PW, LI RK, DHILLON B, MICKLE DA: Endothelin antagonism and interleukin-6 inhibition attenuate the proatherogenic effects of C-reactive protein. Circulation 105: 1890-1896, 2002a.

VERMA S, WANG CH, LI SH, DUMONT AS, FEDAK PW, BADIWALA MV, DHILLON B, WEISEL RD, LI RK, MICKLE DA, STEWART DJ: A self-fulfilling prophecy: C-reactive protein attenuates nitric oxide production and inhibits angiogenesis. Circulation 106: 913-919, $2002 \mathrm{~b}$.

WANG CH, LI SH, WEISEL RD, FEDAK PW, DUMONT AS, SZMITKO P, LI RK, MICKLE DA, VERMA S: C-reactive protein upregulates angiotensin type 1 receptors in vascular smooth muscle. Circulation 107: 17831790, 2003.

WANG TJ, EVANS JC, MEIGS JB, RIFAI N, FOX CS, D'AGOSTINO RB, LEVY D, VASAN RS: Low-grade albuminuria and the risks of hypertension and blood pressure progression. Circulation 111: 1370-1376, 2005.

WELSH P, LOWE GD, CHALMERS J, CAMPBELL DJ, RUMLEY A, NEAL BC, MACMAHON SW, WOODWARD M: Associations of proinflammatory cytokines with the risk of recurrent stroke. Stroke 39: 2226-2230, 2008. 
YUYUN MF, KHAW KT, LUBEN R, WELCH A, BINGHAM S, DAY NE, WAREHAM NJ: A prospective study of microalbuminuria and incident coronary heart disease and its prognostic significance in a British population: the EPIC-Norfolk study. Am J Epidemiol 159: 284-293, 2004. 